\title{
Enhancing pasture-based dairying with supplementary feeds
}

\author{
J.W. PENNO, A.M. BRYANT, K.A. MACDONALD and W.A. CARTER \\ Dairying Research Corporation, Private Bag 3123, Hamilton
}

\section{A bstract}

New Zealand dairy farmers are increasingly using supplementary feeds in an attempt to overcome the quantitative and nutritional limitations of pasture. The use of rolled maize grain and pasture silage supplements was evaluated on a farmlet basis for two seasons. Supplementary feeding resulted in 88 and $82 \mathrm{~g}$ milksolids (MS) $/ \mathrm{kg}$ dry matter (DM) at stocking rates of 3.24 and 4.48 Friesian cows/ha respectively. At the lower stocking rate the responses during spring, summer and autumn were 11, 53 and $113 \mathrm{~g} \mathrm{MS} / \mathrm{kg}$ DM respectively. Small spring responses were attributed to poor use of the spared pasture and cow condition that resulted from supplementary feeding. Large autumn responses were due to extending lactation length. Responses were less variable at the high stocking rate. If large amounts of supplements are used, the stocking rate must be sufficient to ensure high rates of pasture utilisation are maintained. A second farmlet trial compared rolled maize grain, maize silage, and a nutritionally balanced ration at 4.41 Friesian cows/ha. Offering 1.04-1 .23 t DM/cow of supplement increased annual pasture net herbage accumulation by $1.8 \mathrm{t} \mathrm{DM} / \mathrm{ha}$, and MS production by up to $96 \mathrm{~kg} / \overline{\mathrm{cow}}(32 \%)^{-}$. Màize gràm resulted in the largest response, although responses to maize grain and maize silage were similar when the differences in metabolisable energy (ME) content were accounted for. The balanced ration produced the lowest response, both to DM and ME, and was $20 \%$ less than that predicted by the CNCPS nutrition model. ME content is the key nutritional parameter which will determine the likely MS response to supplements.

Keywords: balanced ration, dairying, farm systems, grain, milksolids, silage, supplementary feeding

\section{Introduction}

New Zealand has the lowest farm gate milk price in the developed world. Farmers have learned to cope with a low and decreasing milk price by increasing milksolids (MS) output per unit of land and labour. Output of milk per ha has been increased by increasing pasture production. and using high stocking rates to ensure a large proportion of the available feed is consumed by lactating cows of high genetic merit. Although this is an effective and low cost system, reliance on pasture exposes the inherent weaknesses of a feed-base variable in both its supply and nutritional characteristics.

The current period of relatively stable milk prices has led to an increase in the use of purchased supplementary feed in an attempt to improve per cow performance. To make effective decisions on the integration of these feeds into farming systems farmers require information not only on the factors deteimining the immediate animal production responses, but also on the impact of supplements on the whole farm system.

Reviews of supplementary feeding of pasture-fed dairy cows often discuss the large measured variation in milk responses (Bryant \& Trigg 1982). Edwards \& Parker (1994) claimed that size of the MS response measured in many supplementary feeding trials has been penalised because the supplement gave little consideration to the nutritional status of the pasture, and the particular nutrient requirements of the animals. The limitations of pasture as a feed for dairy cattle have been discussed in New Zealand for many years (Hutton 1962; Edwards \& Parker 1994). Ample information is available regarding the nutritional requirements of dairy cattle (NRC 1989; Fox et al. 1992; AFRC 1993). Ration-balancing principles are being advocated (Edwards \& Parker 1984), yet there is little experimental evidence of the benefits likely to arise in pastoral dairying.

This paper presents results from two trials investigating the response of dairy farm systems to supplementary feeds. The results are used to discuss the principles that will determine supplementary feeding strategies for dairy production.

\section{M ethods}

\section{Experiment 1 .}

A farmlet trial was conducted at the Dairying Research Corporation (DRC) No. 2 Dairy over two seasons (1 June 1993 to 31 May 1995). Penno et al. (1996) described the trial in detail. As part of this work, the performance of three dairy farm systems involving 
purchased cereal grain and pasture silage supplements were compared at low and high stocking rates (Table 1). The control farmlet was stocked at 3.24 cows/ha, and was offered no supplementary feed other than pasture silage conserved on that farmlet. The low (3.24 cows/ ha) and high (4.48 cows/ha) stocked supplement farmlets were offered supplementary feed when milking cows were being underfed $(<15 \mathrm{~kg} \mathrm{DM} /$ cow/day) or were grazing below a post-grazing herbage mass thought to impair pasture regrowth $(<1800 \mathrm{~kg} \mathrm{DM} / \mathrm{ha})$, Rolled maize grain was the predominant supplementary feed and was available up to a maximum daily intake (DMI) of $8 \mathrm{~kg} \mathrm{DM} /$ cow. Purchased pasture silage was used when supplementary feed intake exceeded $50 \%$ of total DMI.

Milk yield and composition were measured by weekly herd test and corrected for calving pattern. Liveweight was measured every 2 weeks after the a.m. milking. Calibrated visual assessment was used to determine pasture herbage mass. Average herbage mass of each paddock was determined weekly, and net herbage accumulation calculated from the increase in herbage mass on ungrazed paddocks. Pre- and postgrazing herbage mass were determined on 3 consecutive days each week and pasture DMI calculated by difference.

\section{Experiment 2}

Three forms of supplementary feed were compared in a farmlet trial at the DRC No. 2 Dairy from 1 June 1995 to 31 May 1996. Four 5.67 ha farmlets were stocked with high genetic merit Friesian cows at 4.41 cows/ha (Table 5). Each farmlet received $240 \mathrm{~kg} \mathrm{~N} / \mathrm{ha} / \mathrm{yr}$. No supplementary feed was available to the control farmlet. Treatments were supplements of either rolled maize grain, maize silage, or a balanced ration. Herds on each

Table 1 Stocking rate, annual supplementary feed offered, and the effect on annual pasture and milksolids production.

\begin{tabular}{lccc}
\hline Farmlet & Control & $\begin{array}{c}\text { Low } \\
\text { Stocked }\end{array}$ & $\begin{array}{c}\text { High } \\
\text { Stocked }\end{array}$ \\
\hline Cows/ha & 3.24 & 3.24 & 4.46 \\
$\begin{array}{l}\text { Supplementary feed intake } \\
\text { Grain (kg DM/cow) }\end{array}$ & 0 & 566 & 1460 \\
Silage (kg DM/cow) & 150 & 201 & 276 \\
Supplement (MJME/cow) & 1500 & 9700 & 22600 \\
$\begin{array}{l}\text { Production } \\
\text { Net herbage accumulation }\end{array}$ & & & \\
$\quad$ (tDM/ha) & 15.9 & 15.4 & 16.4 \\
Milkfat (kg/ha) & 647 & 732 & 977 \\
Milk protein (kg/ha) & 475 & 566 & 740 \\
Response to supplementary feed & & & \\
Milksolids (g/kg DM) & & 88 & 82 \\
Milksolids (g/MJME) & & 6.6 & 6.2 \\
\hline
\end{tabular}

treatment farmlet were offered an equal daily allowance of supplementary. feed using the criteria described for Experiment 1. Refusals were estimated weekly to determine supplement DMI. Weekly pasture samples were taken from paddocks immediately before grazing, and analysed for chemical composition. The balanced ration was formulated to ensure the nutrient and mineral requirements for milksolids (MS) production were met according to the Spartan computer program (van de Haar et al. 1992). Measurements were as described for Experiment 1.

\section{Results}

\section{Experiment 1}

Supplementary feeding resulted in an additional 88 and $82 \mathrm{~g} \mathrm{MS} / \mathrm{kg} \mathrm{DM}$ at the low and high stocking rate respectively (Table 1). At the low stocking rate the MS response to supplements increased as the season progressed (Table 2). Offering supplements to the herd on the low stocked farmlet resulted in only $11 \mathrm{~g} \mathrm{MS} / \mathrm{kg}$ DM in spring (1 June to 31 September), whereas offering supplements in summer (1 October to 31 January) and autumn (1 February to 31 May) resulted in responses of 53 and $134 \mathrm{~g} \mathrm{MS} / \mathrm{kg}$ DM respectively. At the high stocking rate, the responses were less variable with season.

Average liveweight differences between treatments were small, although the control herd was consistently $15-20 \mathrm{~kg} / \mathrm{cow}$ lighter than the herds receiving supplementary feed. At the low stocking rate the average herbage mass of the supplemented and unsupplemented farmlets was similar throughout the year. Despite use of large quantities of supplement, the average herbage mass of the high stocked treatment was consistently 200-400 $\mathrm{kg} \mathrm{DM} / \mathrm{ha}$ lower than that of the control.

Table 2 Effect of supplementary feeding on milksolids (MS) production in sping, summer and autumn.

\begin{tabular}{lccc}
\hline Farmlet & Control & $\begin{array}{c}\text { Low } \\
\text { Stocked }\end{array}$ & $\begin{array}{c}\text { High } \\
\text { Stocked }\end{array}$ \\
\hline 1 June - 1 October & & & \\
Maize grain offered (kg DM/cow) & 0 & 154 & 349 \\
Milksolids (kg/cow) & 99 & 102 & 94 \\
Response (g MS/kg DM) & & 11 & 63 \\
1 October - 31 January & 0 & 117 & 561 \\
Maize grain offered (kg DM/cow) & 179 & 166 & 176 \\
Milksolids (kg/cow) & & 53 & 81 \\
Response (g MS/kg DM) & & & \\
1 February - end of season & 70 & 107 & 108 \\
Days in milk & 0 & 295 & 550 \\
Maize grain offered (kg DM/cow) & 150 & 201 & 276 \\
Pasture silage offered (kg DM/cow) & 67 & 113 & 114 \\
Milksolids (kg/cow) & & 134 & 91 \\
Response (g MS/kg DM) & & & \\
\hline
\end{tabular}


Table 3 Average net herbage accumulation (kg DM/ha) and chemical composition of pasture during Experiment 2.

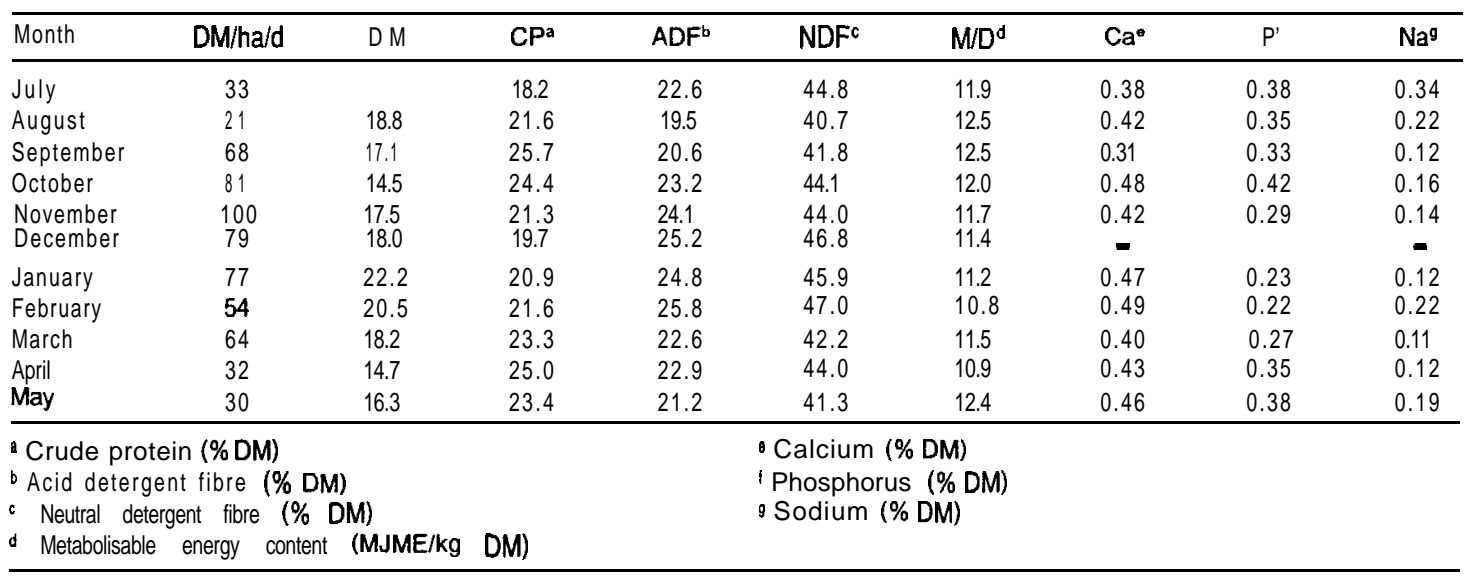

Table 4 Pasture, supplementary feed, and total dry matter intake ( $\mathrm{kg} / \mathrm{cow} / \mathrm{day})$ of the herd on the balanced ration farmlet.

\begin{tabular}{|c|c|c|c|c|c|c|c|c|c|c|}
\hline & Aug & Sep & Oct & Nov & Dec & Jan & Feb & Mar & Apr & May \\
\hline Pasture & 10.8 & 12.2 & 15.2 & 17.0 & 13.0 & 13.5 & 9.4 & 12.9 & 11.3 & 10.3 \\
\hline Maize grain & 0.5 & 1.0 & 0.8 & & & 0.6 & 2.5 & 1.8 & 2.5 & 2.3 \\
\hline Maize silage & 4.6 & 3.5 & 1.7 & & & & 1.2 & 1.0 & 2.6 & 2.0 \\
\hline Copra meal & 1.8 & 1.80 & & & & & & & & \\
\hline Soybean meal & & & & & & 0.60 & 0.75 & & & \\
\hline Tallow & 0.30 & 0.50 & 0.30 & & & 0.20 & 0.25 & 0.25 & 0.25 & 0.25 \\
\hline Blood meal & 0.30 & 0.50 & & & & 0.20 & 0.25 & & & \\
\hline Meat and bone & & & 0.5 & & & & & & & \\
\hline Limestone flour & & 0.10 & 0.1 & & & & & & & \\
\hline Dical phosphate & & 0.10 & & & & & 0.1 & 0.10 & 0.10 & 0.10 \\
\hline Sodium chloride & & & & & & & & 0.05 & 0.05 & 0.05 \\
\hline Total & 18.3 & 19.7 & 18.6 & 17.0 & 13.0 & 15.1 & 14.5 & 16.1 & 16.8 & 15.0 \\
\hline
\end{tabular}

\section{Experiment 2}

Differences in chemical composition of the pasture grown on the individual farmlets were small (Table 3 ). Maize silage became the basis for the balanced ration comprising $49 \%$ of the supplementary DMI/cow (Table 5). Tallow, rolled maize grain, copra and soybean meal increased the energy density of the ration. The blood meal, meat and bone meal and copra provided undegradable protein, and soybean was used to provide a_high_quality rumen degradable protein source. Lime flour, dicalcium phosphate and sodium chloride were used to meet the mineral requirements.

The use of 1.04-1.23 t supplementary feed DM/ cow, and the resultant reduction in grazing pressure, increased annual net herbage accumulation by $1.8 \mathrm{t}$ $\mathrm{DM} / \mathrm{ha}(9.6 \%)$. The increased feeding levels resulting from the supplement and extra pasture produced a 26$33 \%$ increase in MS output of the faimlet systems. The largest responses per $\mathrm{kg}$ DM were obtained from maize grain, and the least from maize silage. Milksolids responses per megajoule of metabolisable energy
Table 5 Annual supplementary feed offered, and the effect on annual pasture and milksolids production.

\begin{tabular}{lcccc}
\hline Farmlet & \multicolumn{5}{c}{$\begin{array}{c}\text { Control } \\
\text { grain }\end{array}$} & $\begin{array}{c}\text { Maize } \\
\text { silage }\end{array}$ & $\begin{array}{c}\text { Balanced } \\
\text { ration }\end{array}$ \\
\hline $\begin{array}{l}\text { Supplementary } \\
\text { MJME/kg D M }\end{array}$ & & & & \\
kg DM/cow & 0 & 13.6 & 10.3 & 12.3 \\
MJME/cow & 0 & 14090 & 1140 & 1231 \\
Production & & & & 15141 \\
Net herbage accumulation & & & & \\
$\quad$ (t DM/ha) & 18.8 & 20.7 & 20.5 & 20.7 \\
Days in milk & 243 & 284 & 283 & 289 \\
Milkfat(kg/cow) & 171 & 223 & 218 & 219 \\
Milk protein (kg/cow) & 130 & 174 & 162 & 170 \\
Milksolids (kg/ha) & 1327 & 1760 & 1671 & 1720 \\
Milksolids Response & & & & \\
g MS/kg DM & & 93 & 69 & 71 \\
g MS/MJME & & 6.8 & 6.7 & 5.8 \\
\hline
\end{tabular}

(MJME) were similar for the three supplementary feed sources (Table 5). 


\section{Discussion}

The annual MS response to the use of supplementary feed in Experiments 1 and 2 were smaller than those measured in other farm systems trials (Fraser \& Leaver 1988; McCallum et al. 1995). Offering supplementary feed in Experiment 1 resulted in $88 \mathrm{~g} \mathrm{MS} / \mathrm{kg} \mathrm{DM}$ at the low stocking rate, and $82 \mathrm{~g} \mathrm{MS} / \mathrm{kg} \mathrm{DM}$ at the high stocking rate. A similar response (93 g MS/kg DM) was obtained when maize grain was offered in Experiment 2 .

\section{Timing of supplementary feeding}

A common assumption is that the marginal response to supplements decreases as lactation progresses (Stockdale \& Trigg 1989). In early lactation a higher proportion of consumed nutrients are partitioned toward milk production and less toward liveweight gain. The opposite occurs in late lactation (Broster \& Thomas 1981). At the low stocking rate in Experiment 1 the total MS response is the accumulation of a negligible spring response, a moderate summer response and a large autumn response. These data suggest that, within the farm system, interactions between the use of supplements, cow condition and average herbage mass may be of greater importance than the changes that occur in the partitioning of nutrients.

Extra feed inputs cause various amounts of additional milk production, pasture substitution and changes in body condition. The increase in milk production that occurs within a few days of starting to feed supplements is known as the 'immediate response'. Over a longer period, extra milk may be produced as a result of improved cow condition or better pasture cover because of substitution; this is known as the 'carry-over effect'. Typically the carry-over effect is equal to, or greater than, the immediate effect (Bryant \& Trigg 1982); however this is dependent on the subsequent utilisation of any spared pasture and cow condition.

Spared pasture will be utilised only if the period of feed deficit continues until the herd returns to graze the particular paddock being grazed at the time of supplementary feeding. Likewise, cow condition spared by supplementary feeding will be of little use if generous feeding would have otherwise allowed any lost cow condition to be replaced shortly after it was mobilised. In Experiment 1 the spring feed deficit was followed by a period of surplus, resulting in a poor carry-over effect. In the same way, poor responses have been measured when supplements are used during a summer feed deficit immediately before a period of good autumn pasture growth (Bryant \& Macdonald 1987). In contrast, the feed deficit on the high stocked farmlet was more severe, allowing carry-over effects to be captured, and resulting in a much larger spring response. Large carryover effects occur when spared pasture and cow condition are utilised during lactation (Clark 1993).

\section{Extending lactation length}

Large responses can be expected if supplements are used to increase feeding levels to extend lactation (Thomson \& Holmes 1995). Much of the additional autumn production achieved on the low stocked farmlet in Experiment 1, and on the treatment farmlets in Experiment 2, can be attributed to extra days in milk.

A dairy herd requires maintenance feeding irrespective of being in milk or dry. The potential lactation length in a seasonal calving herd is 305 days, yet many herds achieve only 240 days in milk. Large responses are obtained when lactation length is extended because the total daily milk production is attributable to the marginal feed input above that required for maintenance.

\section{Stocking rate}

If large amounts of supplements are to be used, the stocking rate must be sufficient to utilise all the available feed. Penno et al. (1996) demonstrated that, in Experiment 1, increasing the total feed supply to the low stocked farmlet would reduce pasture utilisation. The lower net herbage accumulation of the low stocked farmlet (Table 1) is probably a result of reduced pasture utilisation in spring, causing increased senescence and decay. Increasing stocking rate can ensure carry-over effects are fully captured (McCallum et al. 1995) and may also increase pasture utilisation at times of plentiful supply (Fraser \& Leaver 1988). This is demonstrated by the increase in net herbage accumulation of the high stocked farmlet in Experiment 1. Conversely, the low net herbage accumulation of the control farmlets in Experiment 2 is probably due to reducing photosynthetic leaf area by over-grazing at critical times of the season.

\section{Balancing the ration}

The use of large amounts of supplementary feed was able to sustain high levels of per cow performance in both Experiments 1 and 2. Therefore it is unlikely any of the diets had gross nutrient deficiencies. The response appears to be relative to the amount of $\mathrm{ME}$ supplied by the supplement as no additional gains were achieved by offering a balanced supplementary feed.

The milk yield achieved with ration balancing was substantially lower than the Cornell Net Carbohydrate and Protein Model (CNCPS) (Fox et al. 1992) prediction based on the amounts and chemical composition of the pasture and supplementary feeds offered (Figure 1). Despite the use of tallow and other high energy concentrates, the energy density of the 
balanced diet was lower than that of the maize grain. Nevertheless, when the response to the supplementary feed is expressed per unit of ME, the balanced diet resulted in less MS than either the maize grain, or maize silage. Although it is not possible to determine the cause of the low MS response, several factors may have contributed.

Inclusion of a high rate of tallow in spring could have reduced diet digestibility, although it is generally recommended that fats can be safely added to $3-5 \%$ DMI (Palmquist \& Jenkins, 1980).

The NRC recommendations for rumen undegradable, or bypass, protein (UDP) are high relative to other sets of nutritional recommendations (AFRC 1993). Experimentally these have been shown to be excessive (Santos \& Huber 1995). Several New Zealand studies have been unable to demonstrate increased milk production when cows offered generous amounts of pasture have been supplemented with high quality UDP supplements (Salam et al. 1996).

The fermentation characteristics of pasture used within the nutrition models may be inadequately described by current chemical composition standards. Total mixed rations (TMR) have advantages over grazing where components of the diet are inevitably consumed at different times. Despite being offered at pasture, most of the balanced ration was consumed in the first 2-3 hours.
Perhaps the largest constraint to balancing pasturebased diets using tools such as Spartan and the CNCPS is that no consideration is given to the interactions between supplement, cow, pastures and farm system. Herd averages are used to determine both pasture and supplement DMI and the relative proportions of each. This is clearly inappropriate for accurately predicting the nutrient intake of individuals. Nutritional models are probably useful to identify only major nutrient deficiencies in supplementary feeding strategies.

\section{Conclusions}

Successful supplementary feeding strategies are reliant on the availability of a low cost, high quality feed. The greatest responses to supplements will bc obtained by increasing lactation length. Supplements should be used early in a period of feed deficit to ensure carry-over effects are captured. At moderate stocking rates, supplementary feeding during autumn feed deficits is likely to give larger benefits than in spring. Stocking rate must be high enough to balance annual feed requirements with total feed supply to ensure high rates of pasture utilisation are maintained.

This work suggests the use of detailed nutritional recommendations, such as the NRC, are of limited value in balancing supplementary feeds for grazing dairy cows. Based on Experiment 2, the best indicator of the potential

Figure 1 CNCPS predicted milksolids production based on feed USC and composition and actual milksolids production the balanced ration farmlet

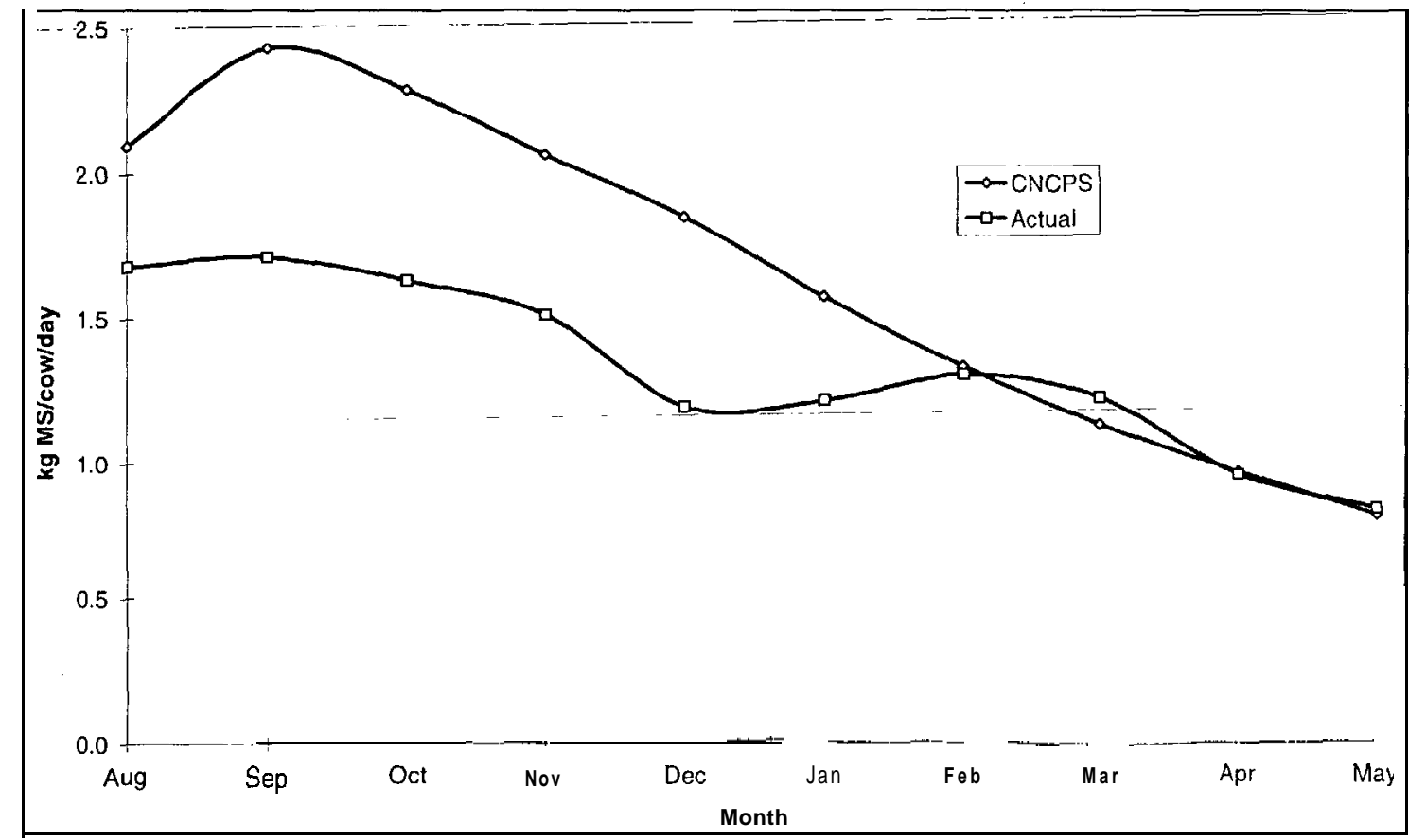


response to a supplementary feed is amount of ME supplied by the supplement. High levels of performance per cow and per ha are attainable when supplements are offered to ensure the energy requirements of the herd are met.

\section{REFERENCES}

AFRC 1993. Energy and Protein Requirements of Ruminants, CAB International Wallingford, UK.

Broster, W.H.; Thomas, C. 1981. The influence of level and pattern of concentrate input on milk output. pp. 49-69. In: Haresign, W. (ed.). Recent advances in animal nutrition. London: Butterworths.

Bryant, A.M.; Trigg, T.E. 1982. The nutrition of the grazing dairy cow in early lactation. pp. 185-207. In: Macmillan, K.L. \& Taufa, V.K. (eds). Dairy production from pasture. Hamilton, NZ: Clark and Matherson Ltd.

Bryant, A.M.; Macdonald, K.A.; 1987. Management of the dairy herd during a dry summer. Proceedings of the Ruakura Farmers Conference 39: 53-56.

Clark, D.A. 1993. Silage for milk production. Proceedings of the Ruakura Farmers Conference 45: 41-46.

Edwards, N.J.; Parker, W.J. 1994. Increasing per cow milk solids production in a pasture-based dairy system by manipulating the diet: a review. Proceedings of the New Zealand Society of Animal Production 54: 267-273.

Fox, D.G.; Sniffen, C.J.; O'Connor, J.D.; Russell, J.B.; Van Soest, P.J. 1992. A Net Carbohydrate and Protein System for evaluating cattle diets: III. Cattle requirements and diet adequacy. Journal of animal science 70: 3578-3596.

Fraser, D.; Leaver, J.D. 1988. A systems study of high and low concentrate inputs for dairy cows: Milk yield and composition, liveweight, feed intake, fertility and health over four years. Journal of research and development in agriculture 5, 2: 93101.

Hutton, J.B. 1962. Studies of the nutritive value of New Zealand dairy pasture. II. Herbage intake and digestibility studies with cattle. New Zealand journal of agricultural research 5: 409-424.

McCallum, D.; Thomson, N.A.; Clough, J.S. 1995. Use of concentrate feed to maintain the feed supply at high stocking rates. Waimate West demonstration farm. Proceedings of the Massey Dairy Farmers Conference 47: 15-19.

NRC 1989. Nutrient Requirements for Dairy Cattle (6th ed.) Washington: National Academy Press.

Palmquist, D.L.; Jenkins, T.C. 1980. Fats in lactation rations: Review. Journal of dairy science 63: 1-14.

Penno, J.W.; Macdonald, K.A.; Bryant, A.M. 1996. The economics of No. 2 Dairy systems. Proceedings of the Ruakura Farmers Conference 48: 1 1-1 9.

Salam, R.; Kool, A.; MacBeth, F.; Van Houtert, M. 1996. Amino acids for lactating dairy cows. Proceedings of the Massey Dairy Farmers Conference 48: 150-1 58.

Santos, F.A.P.; Huber, J.T. 1995. Effects of rumen undegradable protein on dairy cow performance: A 10 year literature review. Journal of dairy science 78, Supplement I: 293.

Stockdale, C.R.; Trigg, T.E. 1989. Effect of pasture feeding levels on the responses of lactating dairy cows to high energy supplements. Australian journal of experimental agriculture 29: 605-611.

Thomson, N.A.; Holmes, C.W. 1995. Supplementary feeding for increased milk production. Proceedings of the Massey Dairy Farmers Conference 47: 2027.

van de Haar, M.; Bucholtz, H.; Beverly, R.; Emery, R.; Allen, M.; Sniffen, C.; Black, R. 1992. Users manual for Spartan dairy ration evaluator/balancer. Version 2. Michigan State University Cooperative Extension Service. 